\title{
カルシウムアルミネート系水和物を考慮したセメント硬化体の比表面積の 推定方法に関する基礎的研究
}

\author{
寺戸政成 ${ }^{* 1}$ 須田裕哉 ${ }^{* 2}$ 斎藤豪 ${ }^{* 3}$ 佐伯竜彦 ${ }^{* 3}$
}

\begin{abstract}
*1 新潟大学 大学院自然科学研究科環境科学専攻 ( $7950-2181$ 新潟県新潟市西区五十嵐 2 の町 8050)
*2＼cjkstart豊田工業高等専門学校 環境都市工学科 (下 471-8525 愛知県豊田市栄生町 2-1)

*3 新潟大学 工学部建設学科 ( ₹950-2181 新潟県新潟市西区五十嵐 2 の町 8050)
\end{abstract}

\begin{abstract}
要旨 : 本研究ではカルシウムアルミネート系水和物を考慮したセメント硬化体の比表面積の推定方法の検 討を目的とし、合成アルミネート相を用いて水和反応の検討を行い、カルシウムアルミネート系水和物の 影響を考慮したセメント硬化体全体の比表面積の推定を行った。その結果、 $\mathrm{C}_{3} \mathrm{AH}_{6}$ 生成量とアルミネー 卜相の反応率には水結合材比によらず一定の関係があることがわかった。また、セメント硬化体中のカル シウムアルミネート系水和物の比表面積の推定では、アルミネート相の反応率と $\mathrm{C}_{3} \mathrm{AH}_{6}$ 生成量のみを把 握すればよいことを明らかにし、各水和物を定量した場合と同等の精度でセメント硬化体全体の比表面積 を推定することが可能となった。
\end{abstract}

キーワード：カルシウムアルミネート系水和物、物理的性質、比表面積、アルミネート相、 $\mathrm{C}_{3} \mathrm{AH}_{6}$

\section{1. はじめに}

水和物の物理的性質の一つである比表面積はセメント 硬化体中のイオンの拡散や吸着、収縮といった現象と密 接な関係があることが知られている。著者らは以前から 主要な水和物である C-S-H に着目し、C-S-H の組成 と比表面積の関係について研究を行ってきた。しかし、 セメント硬化体中では C-S-H 以外にも水和物が生成し、 比表面積の評価に扔いてはカルシウムアルミネート系水 和物を考慮する必要があることが指摘されている1)。

また、近年ではセメント製造の際に産業副産物を原料 として使用することが多くなり、セメント中でのアルミ ネート相の割合が増加することが予想されている ${ }^{2)}$ 。こ のような観点からもセメント硬化体中のアルミネート相 の水和反応の詳細を把握し、セメント硬化体中で生成さ れるカルシウムアルミネート系水和物の比表面積を適切 に評価することは重要である。

そこで本研究では、基礎的な検討として、純薬より合 成したアルミネート相を用いて水結合材比、養生温度、 水酸化カルシウム・石亮の共存がアルミネート相の水和 反応に及ぼす影響を検討した。さらに、カルシウムアル ミネート系水和物を考慮したセメント硬化体の比表面積 の推定を行った。

\section{2. 実験概要}

\section{1 アルミネート相の合成}

実際のセメント中に含まれているアルミネート相 $\left(\mathrm{C}_{3} \mathrm{~A}\right)$ はナトリウム $(\mathrm{Na})$ やカリウム $(\mathrm{K})$ などを含んでい
る。このような $\mathrm{C}_{3} \mathrm{~A}$ を合成することを目的として、山 口・高木 ${ }^{3)}$ らが報告しているセメントクリンカーの組成 を参考に $\mathrm{C}_{3} \mathrm{~A}$ の合成を行った。その結果、 $\mathrm{C}_{3} \mathrm{~A}$ 以外に フェライト相 $\left(\mathrm{C}_{4} \mathrm{AF}\right)$ の生成が確認されたため、酸化鉄 (III) $\left(\mathrm{Fe}_{2} \mathrm{O}_{3}\right)$ を減らし、酸化アルミニウム $\left(\mathrm{Al}_{2} \mathrm{O}_{3}\right)$ を増 やして合成を行い、 $\mathrm{C}_{4} \mathrm{AF}$ の生成がないこと、また、焼 成度の指標となる $\mathrm{f}-\mathrm{CaO}$ が存在しないことを粉末 $\mathrm{X}$ 線 回折 (XRD) による定性分析で確認した。これを $\mathrm{C}_{3} \mathrm{~A}$ ( I ) と称す。物理的性質㧍よび化学組成を Table 1 に示す。 使用した試薬は全て特級試薬とし、目標のモル比となる よう秤取し、試薬をメノウボールミルに入れ、エタノー ルを用いて湿式混合を行った。混合後、エタノールを十 分に乾燥させた後、試料を磁性ルッボ内に入れ電気炉に

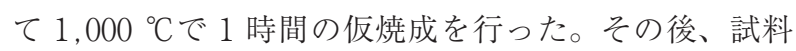

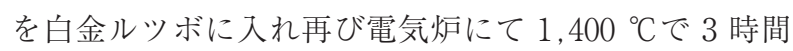
焼成を行い、焼成後、炉外にて試料を急泠し、90 $\mu \mathrm{m}$ 以 下に粉砕し、ブレーン值が $4,250 \mathrm{~cm}^{2} / \mathrm{g}$ になるよう調節 した。

\section{2 アルミネート相の水和試料の作製}

水和試料の水結合材比 (W/B) は既往の研究 ${ }^{4}$ を参考 に $70 \% 、 100 \% 、 120 \%$ とし、養生温度を $20{ }^{\circ} \mathrm{C}$ とした。 また、養生温度の影響を検討するためにW/B 100 \%の 試料において、養生温度 $40{ }^{\circ} \mathrm{C} に お け る$ 実験も行った。 セメント中での水和反応を検証するために水酸化カルシ ウム $(\mathrm{CH})$ 及び石膏 $\left(\mathrm{C}_{\bar{S}} \mathrm{H}_{2}\right)$ を添加した。また、比較のた めにさらに、 $\mathrm{C}_{3} \mathrm{~A}$ と $\mathrm{CH} 、 \mathrm{C}_{3} \mathrm{~A}$ のみでも検討を行った。 これら 2 つの試料の水結合材比は $100 \%$ と、養生温 
Table 1 Physical properties and chemical compositions of $\mathrm{C}_{3} \mathrm{~A}$ and OPC

\begin{tabular}{|c|c|c|c|c|c|c|c|c|c|c|c|}
\hline \multirow{2}{*}{ Binder } & \multirow{2}{*}{$\begin{array}{l}\text { Density } \\
\left(\mathrm{g} / \mathrm{cm}^{3}\right)\end{array}$} & \multirow{2}{*}{$\begin{array}{l}\text { Blaine } \\
\left(\mathrm{cm}^{2} / \mathrm{g}\right)\end{array}$} & \multirow{2}{*}{$\begin{array}{l}\text { Ig.loss } \\
(\%)\end{array}$} & \multicolumn{8}{|c|}{ Chemical composition (\%) } \\
\hline & & & & $\mathrm{SiO}_{2}$ & $\mathrm{Al}_{2} \mathrm{O}_{3}$ & $\mathrm{Fe}_{2} \mathrm{O}_{3}$ & $\mathrm{CaO}$ & $\mathrm{MgO}$ & $\mathrm{SO}_{3}$ & $\mathrm{Na}_{2} \mathrm{O}$ & $\mathrm{K}_{2} \mathrm{O}$ \\
\hline $\mathrm{C}_{3} \mathrm{~A}(\mathrm{I})$ & 3.05 & 4,250 & 0.40 & 6.00 & 31.84 & 2.00 & 54.65 & 2.01 & - & 2.32 & 1.18 \\
\hline $\mathrm{C}_{3} \mathrm{~A}(\mathrm{II})$ & 3.07 & 4,370 & 0.05 & 6.01 & 31.90 & 2.00 & 56.12 & 2.02 & - & 0.78 & 1.18 \\
\hline $\mathrm{C}_{3} \mathrm{~A}(\mathrm{III})$ & 3.03 & 4,280 & 0.32 & 6.00 & 31.80 & 1.99 & 53.16 & 2.01 & - & 3.87 & 1.17 \\
\hline $\mathrm{C}_{3} \mathrm{~A}(\mathrm{IV})$ & 3.03 & 4,500 & 0.00 & - & 37.73 & - & 62.27 & - & - & - & - \\
\hline OPC & 3.16 & 3,480 & 0.62 & 21.36 & 5.28 & 2.66 & 65.02 & 1.46 & 2.08 & 0.29 & 0.48 \\
\hline
\end{tabular}

Table 2 Mix proportions of $\mathrm{C}_{3} \mathrm{~A}-\mathrm{CH}-\mathrm{C} \overline{\mathrm{S}}$ systems

\begin{tabular}{|c|c|c|c|c|c|c|}
\hline \multirow{3}{*}{ Composition } & Hydration time & W/B & Curing temperature & $\mathrm{C}_{\bar{S}} \mathrm{H}_{2} / \mathrm{C}_{3} \mathrm{~A}$ & $\mathrm{CH} / \mathrm{C}_{3} \mathrm{~A}$ & Cubic : Orthorhombic \\
\cline { 2 - 7 } & $($ day $)$ & $(\%)$ & $\left({ }^{\circ} \mathrm{C}\right)$ & $(\mathrm{mol} / \mathrm{mol})$ & $(\mathrm{g} / \mathrm{g})$ & $(\%)$ \\
\hline \multirow{5}{*}{$\mathrm{C}_{3} \mathrm{~A}+\mathrm{CH}+\mathrm{C} \overline{\mathrm{S}}$} & $0.25,0.5,1,3,7,28$ & 70 & 20 & 0.5 & 1.0 & $57.07: 42.93$ \\
\cline { 2 - 7 } & $0.25,0.5,1,3,7,28$ & 100 & 20 & 0.5 & 1.0 & $57.07: 42.93$ \\
\cline { 2 - 7 } & $0.25,0.5,1,3,7,28$ & 120 & 20 & 0.5 & 1.0 & $57.07: 42.93$ \\
\cline { 2 - 7 } & $0.25,0.5,1,3,7,28$ & 100 & 40 & - & 1.0 & $57.07: 42.93$ \\
\hline $\mathrm{C}_{3} \mathrm{~A}+\mathrm{CH}$ & $0.25,0.5,1,3,7,28$ & 100 & 20 & - & - & $57.07: 42.93$ \\
\hline $\mathrm{C}_{3} \mathrm{~A}$ & $0.25,0.5,1,3,7,28$ & 100 & 20 & 0.5 & 1.0 & $25.84: 74.93$ \\
\hline \multirow{2}{*}{$\mathrm{C}_{3} \mathrm{~A}+\mathrm{CH}+\mathrm{CS}$} & $0.25,0.5,1,3,7,28$ & 100 & 20 & 1.0 & $75.34: 24.66$ \\
\cline { 2 - 7 } & $0.25,0.5,1,3,7,28$ & 100 & 20 & & & 1.5 \\
\hline
\end{tabular}

度は $20{ }^{\circ} \mathrm{C}$ とた。また、 $\mathrm{C}_{3} \mathrm{~A}$ の結晶構造の差異が $\mathrm{C}_{3} \mathrm{~A}$ の水和反応に及ぼす影響を検討するため、2.1 で示した $\mathrm{C}_{3} \mathrm{~A}(\mathrm{I})$ ) 合成時にナトリウムの量を調節することで立 方晶と斜方晶の含有割合を変化させた $\mathrm{C}_{3} \mathrm{~A}(\mathrm{II}) 、 \mathrm{C}_{3} \mathrm{~A}$ （III）を合成した。物理的性質および化学組成を Table 1 に示す。 $\mathrm{C}_{3} \mathrm{~A}(\mathrm{II}) 、($ III) を用いたペーストにおいても石 膏と $\mathrm{CH}$ を添加して W/B を $100 \%$ 、養生温度を $20{ }^{\circ} \mathrm{C}$ として水和させた。

測定材齢はすべて 0.25 日、0.5 日、1 日、3 日、7 日、 28 日とした。Table 2 に配合と実験条件を示す。

練混ぜ水には沸騰・脱気し、養生温度と同じ温度に調 節したイオン交換水を用いた。練混ぜ後、スチロール棒 瓶に詰め、炭酸化を防ぐために窒素封入を行い、所定の 養生温度にて測定材齢に達するまで密封養生を行った。

\section{3 水和物の合成}

本研究では、カルシウムアルミネート系水和物の諸物 性を評価するため合成 $\mathrm{C}_{3} \mathrm{~A}$ を水和させてエトリンガイ ト、モノサルフェートを合成した。用いた合成 $\mathrm{C}_{3} \mathrm{~A}$ は 2.1、2. 2 に記述した $\mathrm{C}_{3} \mathrm{~A}(\mathrm{I}) 、(\mathrm{II}) 、(\mathrm{III})$ とは異なり $\mathrm{Na} 、 \mathrm{~K}$ などの微量成分を含まないものとした。以後 2.1、 2.2 で記述した $\mathrm{C}_{3} \mathrm{~A}$ ( I )、（II)、（III）と混同を避けるた め 2.3 で用いた $\mathrm{C}_{3} \mathrm{~A}$ を $\mathrm{C}_{3} \mathrm{~A}(\mathrm{IV})$ と表記する。 $\mathrm{C}_{3} \mathrm{~A}(\mathrm{IV})$ の合成ではまず炭酸カルシウムと酸化アルミニウムをモ ル比 $3: 1$ となるよう秤量した。試薬の混合はエ夕ノー ルを用いて湿式混合で行った。試料は $1,400{ }^{\circ} \mathrm{Cで} 3$ 時 間焼成した。その後、粉砕混合を行い、再び電気炉に て焼成した。これらの操作を合計 3 回繰り返し合成し た。得られた $\mathrm{C}_{3} \mathrm{~A}(\mathrm{IV})$ は、ボールミルにてブレーン值 を $4,500 \mathrm{~cm}^{2} / \mathrm{g}$ に調整した。
エトリンガイトとモノサルフェートは、合成 $\mathrm{C}_{3} \mathrm{~A}(\mathrm{IV})$ と二水石膏をそれぞれモル比 $1: 3$ および $1: 1$ で混合 して合成した。イオン交換水を用いて、混合試料を水粉 体比 10 で練混ぜを行い、その後、スチロール棒瓶に詰め、 窒素を封入し $20{ }^{\circ} \mathrm{C}$ 恒温室内で、14 日間反応させた。

$\mathrm{C}_{3} \mathrm{AH}_{6}$ は、 $\mathrm{C}_{3} \mathrm{~A}(\mathrm{IV})$ とイオン交換水を水粉体比 1.0 で練り混ぜ、窒素を封入し $40{ }^{\circ} \mathrm{C}$ の恒温室内にて 28 日 間反応させて合成した。

$\mathrm{C}_{4} \mathrm{AH}_{13}$ の合成は、既報 ${ }^{5)}$ の方法を参考に行った。ア ルミン酸ナトリウム $\left(\mathrm{NaAlO}_{2}\right)$ と酸化カルシウム $(\mathrm{CaO})$ を モル比 1:2 で混合した。水粉体比 10 で練り混ぜを行 い、20 ${ }^{\circ} \mathrm{C}$ の恒温室内にて 28 日間反応させた。なお、反 応を促進させる目的で、定期的に容器を振とうし、上澄 み液と沈殿物を混合させた。なお、 $\mathrm{C}_{4} \mathrm{AH}_{13}$ に関しては 結合水量による組成の変化が考えられるが、本研究では $\mathrm{C}_{4} \mathrm{AH}_{13}$ をこれらの水和物の代表組成として取り扱った。

水酸化カルシウムは関東化学製の特級試薬を用いた。

各合成水和物はXRDにて定性分析を行った。試料の 同定を行った結果、モノサルフェート中にエトリンガイ トのピークが確認されたため、選択溶解法 ${ }^{6}$ によりエト リンガイトを除去した。合成カルシウムアルミネート水 和物の XRD チャートを Fig. 1 に示す。各水和物の組 成は XRD/Rietveld 解析および熱重量分析 (TGA) 結果 により算出した。R.H.11 \%においてエトリンガイトが $\mathrm{C}_{6} \mathrm{~A} \overline{\mathrm{S}} \mathrm{H}_{28.8}$ モノサルフェートが $\mathrm{C}_{4} \mathrm{~A} \overline{\mathrm{S}} \mathrm{H}_{11.7} 、 \mathrm{C}_{3} \mathrm{AH}_{6}$ が $\mathrm{C}_{3} \mathrm{AH}_{6} 、 \mathrm{C}_{4} \mathrm{AH}_{13}$ が $\mathrm{C}_{4} \mathrm{AH}_{13.3}$ であった。

\section{4 セメント水和試料の作製}

普通ポルトランドセメント $(\mathrm{OPC})$ を水和させて比 表面積を測定し、比表面積推定手法の検証を行った。 
Table 3 Mineral compositions of OPC

\begin{tabular}{|c|c|c|c|c|c|c|c|c|c|}
\hline Binder & $\mathrm{C}_{3} \mathrm{~S}$ & $\mathrm{C}_{2} \mathrm{~S}$ & $\mathrm{C}_{3} \mathrm{~A}$ & $\mathrm{C}_{4} \mathrm{AF}$ & $\mathrm{C}_{\bar{S}} \mathrm{H}_{2}$ & $\mathrm{CS}_{0.5}$ & $\mathrm{f}-\mathrm{CaO}$ & $\mathrm{CaCO}_{3}$ & $\mathrm{MgO}$ \\
\hline $\mathrm{OPC}$ & 58.2 & 19.2 & 9.5 & 9.3 & 0.1 & 1.8 & 0.1 & 0.4 & 0.8 \\
\hline
\end{tabular}

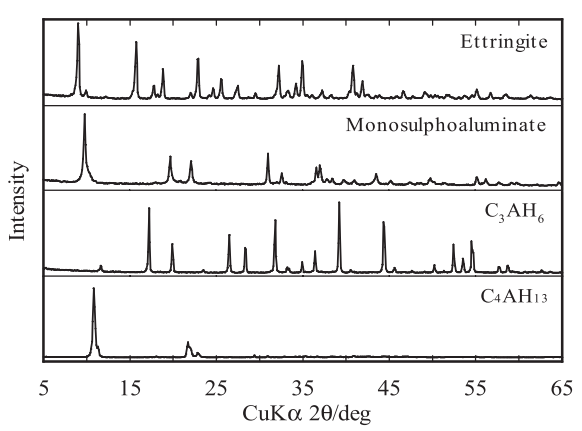

Fig. 1 XRD paterns of calcium aluminate hydrates

Table 1 に用いたセメントの物理的性質および化学組成 を、Table 3 に XRD/Rietveld 解析により求めた鉱物組 成を示す。セメントペーストの水セメント比は $35 \%$ 、 $45 \% 、 55 \%$ とし、養生温度は $20{ }^{\circ} \mathrm{C}$ とた。

また、測定材齞は 1 日、3 日、7 日、28 日、91 日、 182 日、365 日とした。Table 4 に配合を示す。 2.2 で 記述した $\mathrm{C}_{3} \mathrm{~A}$ の水和試料と同じ方法で水和試料を作製 した。

\section{5 水和試料の分析}

(1) 前処理方法

所定の日数に達した後、スラリー状の合成水和物は吸 引濾過にて固液分離を行った。硬化体は所定の材齢に達 した後、スチロール棒瓶から取り出し $5 \mathrm{~mm}$ 程度に粗砕 した。粗砕した試料をアセトンに浸漬し、水和停止を 行った。2 日後にアスピレーターを用いて減圧環境下で アセトンを揮発させ、相対湿度(R.H.) 11 \%の真空デシ ケーター内で試料質量が恒量となるまで乾燥させた。試 料乾燥後、ボールミルで粉砕し、90 $\mu \mathrm{m}$ のふるいを全通 させた。粉砕後、水和物の分析に用いる試料は R.H.11 \% で乾燥し、水蒸気吸着量の測定に用いる試料は $110{ }^{\circ} \mathrm{C}$ 乾燥を行った。

(2) 結合水量の測定

水和試料の結合水量は、熱重量測定装置(TGA)を用 いて測定した。測定は、 $\mathrm{N}_{2}$ フロー環境下で昇温速度 $20{ }^{\circ} \mathrm{C} / \mathrm{min}$ で行い、R.H.11 \% 乾燥試料では、50 ${ }^{\circ} \mathrm{C}$ から $1,000{ }^{\circ} \mathrm{C}$ 重量減少量を、 $110{ }^{\circ} \mathrm{C}$ 乾燥試料では $110{ }^{\circ} \mathrm{C}$ ら $1,000{ }^{\circ} \mathrm{C}$ ま゙の重量減少量を試料の結合水量とした。

(3) 相組成の測定

水和試料の相組成は、XRD/Rietveld 解析により測定 した。定量には内部標準法を用いた。内部標準物質には 特級試薬の $\alpha-\mathrm{Al}_{2} \mathrm{O}_{3}$ を用い、試料質量に対し内割りで $10 \%$ 混合した。解析ソフトは、Topas 4.2(Bruker AXS

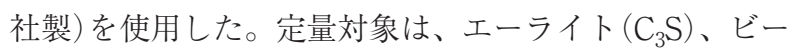

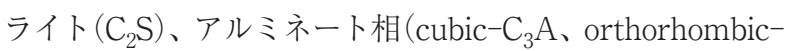
$\left.\mathrm{C}_{3} \mathrm{~A}\right) 、$ フェライト相 $\left(\mathrm{C}_{4} \mathrm{AF}\right)$ 、二水石膏 $\left(\right.$ Gypsum : $\left.\mathrm{C} \overline{\mathrm{S}} \mathrm{H}_{2}\right)$ 、
Table 4 Mix proportions of OPC

\begin{tabular}{|c|c|c|c|}
\hline Symbol & Binder & W/B (\%) & Hydration time (day) \\
\hline \multirow{2}{*}{ N35 } & \multirow{4}{*}{ OPC } & 35 & $1,3,7,28,91,182,365$ \\
\cline { 4 - 4 } N45 & 45 & $1,3,7,28,91,182,365$ \\
\cline { 4 - 4 } & & 55 & $1,3,7,28,91,182,365$ \\
\hline
\end{tabular}

水酸化カルシウム $(\mathrm{CH})$ 、炭酸化カルシウム $\left(\mathrm{CaCO}_{3}\right)$ 、

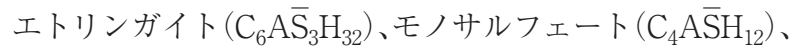

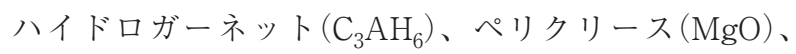

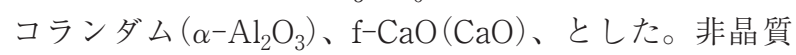
量は内部標準物質の定量值から式[1]によって算出した。

$$
\begin{aligned}
& G=[100(A-R) / A] \cdot[100 /(100-R)] \\
& \text { ここに、G: 非晶質量 }(\%) \\
& R: \alpha-\mathrm{Al}_{2} \mathrm{O}_{3} \text { の添加量 (\%) } \\
& A: \alpha-\mathrm{Al}_{2} \mathrm{O}_{3} \text { の定量值 (\%) }
\end{aligned}
$$

なお、Rietveld 解析では定量できない水和物である $\mathrm{C}-\mathrm{S}-\mathrm{H} 、 \mathrm{C}_{4} \mathrm{AH}_{13} 、 \mathrm{C}_{3} \mathrm{FH}_{6}$ については著者らの既報 ${ }^{1)}$ 結果を用いた。まず、Rietveld 解析で得た各クリンカー の反応率および定量可能である水和物の相組成を用いて 残りの $\mathrm{CaO}(\mathrm{C})$ 等の各成分を算出し、物質収支から相組 成を計算した。

（4）水蒸気吸着量の測定

水蒸気吸着量の測定は、 $110{ }^{\circ} \mathrm{C}$ 乾燥後の試料を用い た。本研究では、110 ${ }^{\circ} \mathrm{C}$ 乾燥を R.H.0％と定義した。飽 和塩類を用いて $20{ }^{\circ} \mathrm{C}$ 環境下で調湿したデシケーター内 にて、試料の質量が恒量になるまで静置し水蒸気吸着量 を得た。なお、調湿に用いた飽和塩類は、塩化リチウム (R.H.11 \%)、酢酸カリウム (R.H.22％)、塩化マグネシ ウム六水和物 (R.H.33 \%)である。各塩類を用いて湿度 を調整したデシケーター内には、試料とともに温湿度セ

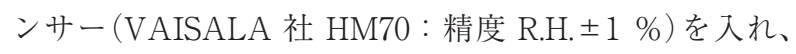
湿度の確認を行った。試料質量測定時の湿度は、セン サーの測定では $10.95 \%$ 、21.01％、33.30％であったが、

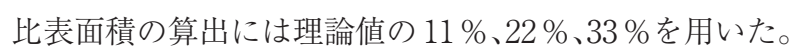

\section{3. 実験結果および考察}

\section{1 合成水和物の比表面積}

水蒸気吸着実験により得た各種合成水和物の比表面 積を Table 5 に示す。表より、カルシウムアルミネー 卜系水和物のうちエトリンガイト (AFt 相) とモノサル フェート $\left(\mathrm{AFm}\right.$ 相) および $\mathrm{C}_{4} \mathrm{AH}_{13}$ の比表面積は同程度 の值 (約 $200 \mathrm{~m}^{2} / \mathrm{g}$ ) であった。 $\mathrm{C}_{3} \mathrm{AH}_{6}$ の比表面積は、他 の 3 水和物と比較して小さな值 $\left(12 \mathrm{~m}^{2} / \mathrm{g}\right)$ であった。 

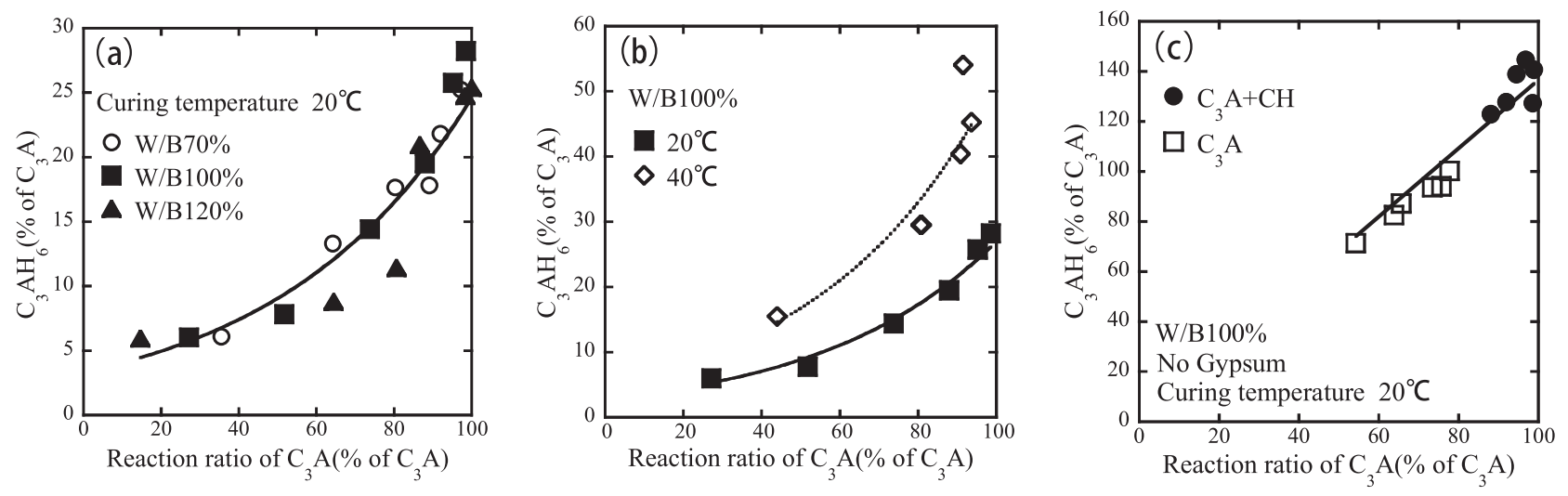

Fig. 2 Relation between reaction ratio of $\mathrm{C}_{3} \mathrm{~A}$ and production amount of hydrogarnet

Table 5 Specific surface area of $\mathrm{CH}$ and calcium aluminate hydrates

\begin{tabular}{|c|c|}
\hline Hydrates & specific surface area $\left(\mathrm{m}^{2} / \mathrm{g}\right)$ \\
\hline $\mathrm{CH}$ & 19 \\
\hline $\mathrm{AFt}$ & 194 \\
\hline $\mathrm{Afm}$ & 207 \\
\hline $\mathrm{C}_{4} \mathrm{AH}_{13}$ & 200 \\
\hline $\mathrm{C}_{3} \mathrm{AH}_{6}$ & 12 \\
\hline
\end{tabular}

よって、 $\mathrm{C}_{3} \mathrm{AH}_{6}$ がセメント硬化体中のカルシウムア ルミネート系水和物の比表面積に及ぼす影響は、非常に 小さいものと考えられる。

\section{2 アルミネート相の水和反応}

本研究では、 $\mathrm{C}_{3} \mathrm{~A}$ の水和により生成されるカルシウ ムアルミネート系水和物の中で他の水和物と比表面積が 異なる $\mathrm{C}_{3} \mathrm{AH}_{6}$ に着目して検討を行った。

Fig. $2(\mathrm{a}) \sim(\mathrm{c})$ に $\mathrm{C}_{3} \mathrm{~A}$ の反応率と $\mathrm{C}_{3} \mathrm{AH}_{6}$ の生成量の 関係を示す。Fig. $2(\mathrm{a})$ より、本研究の $\mathrm{W} / \mathrm{B}$ の範囲では $\mathrm{C}_{3} \mathrm{~A}$ の反応率と $\mathrm{C}_{3} \mathrm{AH}_{6}$ 生成量の関係は $\mathrm{W} / \mathrm{B}$ に依存し なかった。また、 $\mathrm{C}_{3} \mathrm{~A}$ 反応率の増加とともに $\mathrm{C}_{3} \mathrm{AH}_{6}$ 生 成量が増加し、両者の関係は以下の式[2]で回帰できた。 これは検討に用いた試料には石膏が添加されているた め、材齢初期の反応率の低い範囲 (60\%以下)では $\mathrm{AFt}$ 相が生成し、石膏消費後に $\mathrm{C}_{3} \mathrm{AH}_{6}$ 生成量が増加したた めと考えられる。

$$
\begin{aligned}
& P_{H g}=3.33 \times \exp (0.02 \alpha) \\
& \text { 己こに、 } P_{H g}: \mathrm{C}_{3} \mathrm{AH}_{6} \text { 生成量 }\left(\text { mass } \% \text { of } \mathrm{C}_{3} \mathrm{~A}\right) \\
& \alpha: \text { アルミネート相の反応率 }(\%)
\end{aligned}
$$

また、Fig. 2(b)より、 $\mathrm{C}_{3} \mathrm{AH}_{6}$ 生成量は養生温度に大 きく依存していた。養生温度が高いほど、生成される $\mathrm{C}_{3} \mathrm{AH}_{6}$ 量は多くなったが、Fig. 2(a) と同様に、どちら の養生温度においても反応率と $\mathrm{C}_{3} \mathrm{AH}_{6}$ 生成量の関係は 指数関数で回帰できた。

Fig. 2(c)に、石膏無添加の場合の結果を示す。 $\mathrm{C}_{3} \mathrm{~A}$

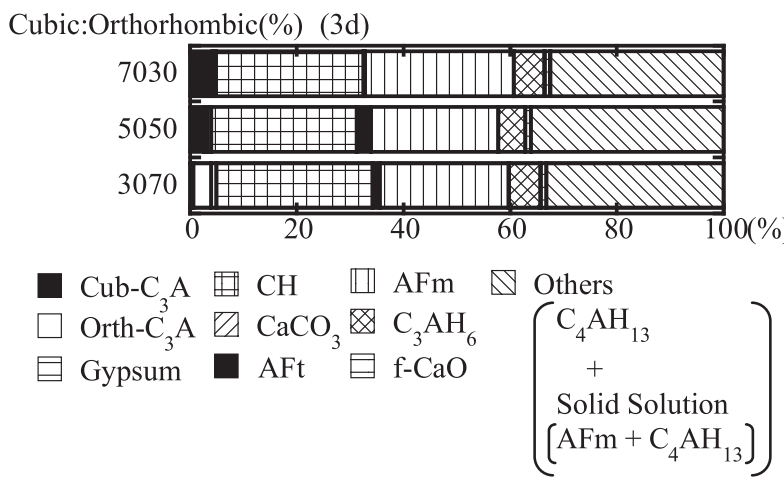

Fig. 3 Composition of hydration products

の反応率と生成される $\mathrm{C}_{3} \mathrm{AH}_{6}$ 量の関係は直線で回帰さ れた。また、両者の関係は水酸化カルシウムの有無によ らず同じであることから、水酸化カルシウムの有無は $\mathrm{C}_{3} \mathrm{AH}_{6}$ の生成には影響を及ぼさないと考えられる。

$\mathrm{C}_{3} \mathrm{~A}$ の結晶構造の違いが $\mathrm{C}_{3} \mathrm{AH}_{6}$ の生成量に及ぼす影 響について、材齢 3 日における相組成を Fig. 3 に示す。 図中の Others には $\mathrm{C}_{4} \mathrm{AH}_{13}$ や $\mathrm{AFm}$ 相と $\mathrm{C}_{4} \mathrm{AH}_{13}$ の固 溶体が含まれる。Fig. 3 より、立方晶・斜方晶の割合を 変化させた配合において $\mathrm{C}_{3} \mathrm{AH}_{6}$ の生成量に大きな変化 は見られなかった。従って、本研究の範囲では $\mathrm{C}_{3} \mathrm{~A} の$ 水和反応に拈ける $\mathrm{C}_{3} \mathrm{AH}_{6}$ の生成に関して結晶構造の差 異による影響は見られなかった。

\section{3 セメント硬化体の比表面積の推定}

（1）セメント硬化体の比表面積の推定方法

セメント硬化体の比表面積は硬化体を構成する水和物 の比表面積の和であることから式[3]で求めることがで きる。

$$
A_{h p c}=\sum A_{i} \cdot X_{i}
$$

ここに、 $A_{h p c}$ : セメント硬化体の比表面積 $\left(\mathrm{m}^{2} / \mathrm{g}\right)$ $A_{i}:$ 各水和物の比表面積 $\left(\mathrm{m}^{2} / \mathrm{g}\right)$ $X_{i}$ : 各水和物の相組成 (mass\% of dry sample) 


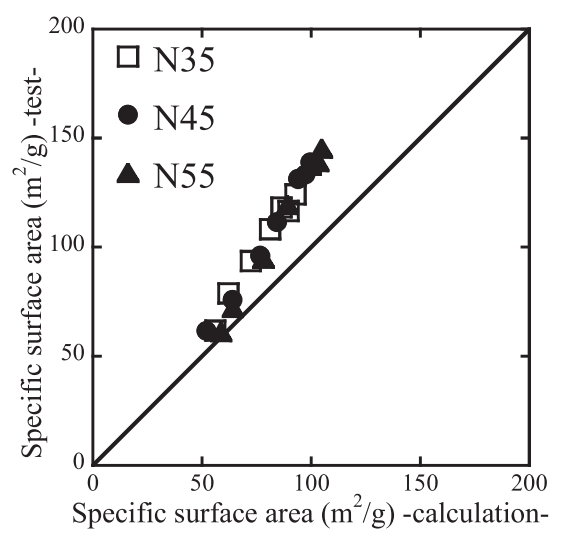

Fig. 4 Comparison between test value and calculation value of specific surface area in consideration of $\mathrm{C}-\mathrm{S}-\mathrm{H}$ and $\mathrm{CH}$

C-S-H の比表面積 $\left(\mathrm{A}_{\mathrm{CSH}}\right)$ は $\mathrm{CaO} / \mathrm{SiO}_{2}$ モル比 (C/S 比)

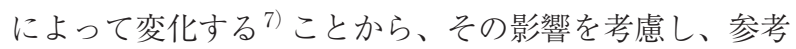
文献 ${ }^{1)}$ の中で示されている下記の式[4]を用いて求めた。 C/S 比は前述したように2.5(4)で記載した物質収支に より求めた。また、 $\mathrm{C}_{3} \mathrm{FH}_{6}$ の比表面積は $\mathrm{C}_{3} \mathrm{AH}_{6}$ と同じ と仮定した。なお、本研究において実際のセメント硬化 体中の水和物と 3.1 で示した合成水和物の比表面積は 同じであると仮定した上で推定を行った。

$$
A_{C S H}=269.3-325.1 \log (C / S)
$$

\section{（1）セメント硬化体の比表面積の推定結果}

Fig. 4 に主要な水和物である $\mathrm{C}-\mathrm{S}-\mathrm{H}$ と $\mathrm{CH}$ の比表面 積のみを考慮した場合の比表面積の計算值と実測值の比 較を示す。計算值は $\mathrm{C} / \mathrm{S}$ 比別の $\mathrm{C}-\mathrm{S}-\mathrm{H}$ の比表面積と $\mathrm{C}-\mathrm{S}-\mathrm{H}$ 生成量、 $\mathrm{CH}$ の比表面積、 $\mathrm{CH}$ 生成量から算出し た。Fig. 4 より、計算值は実際の比表面積を過小評価し ており、C-S-H、CH 以外の水和物の比表面積を考慮す る必要があると考えられる。比表面積が大きくなるほど 計算值と実測值の差が大きくなる理由は、反応が進むに つれて、比表面積の小さい未水和セメントが減少し、比 表面積の大きい水和物の生成量が増加していくことが原 因であると考えられる。

Fig. 5 に全ての水和物の生成量と比表面積を用いて算 出した硬化体比表面積の計算值と実測值を示す。カルシ ウムアルミネート系水和物を考慮したことにより Fig. 4 より計算值と実測值の差が小さくなり、推定精度が向上 した。セメント硬化体の比表面積を推定する場合、カル シウムアルミネート系水和物の影響も考慮しなければな らないことが確認できる。また、各水和物の生成量が予 測できれば個々の水和物の比表面積を積算することで、 硬化体全体の比表面積を推定できると考えられる。

\section{4 アルミネート相の反応率と $\mathrm{C}_{3} \mathrm{AH}_{6}$ 生成量を用いた セメント硬化体比表面積の簡易推定方法}

産業廃棄物使用の増大によりセメント中の間隙層の 増大が今後見达まれる。それに伴い、 $\mathrm{C}_{4} \mathrm{AH}_{13}$ 等の結合

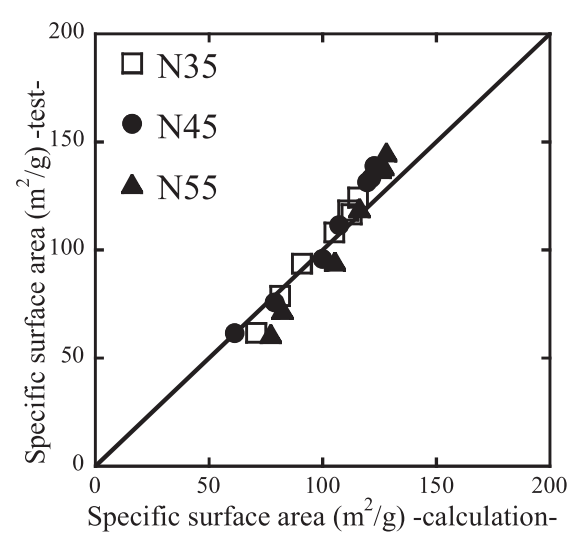

Fig. 5 Comparison between test value and calculation value of specific surface area in consideration of all hydrates

水量変化や $\mathrm{C}_{4} \mathrm{AH}_{13}$ と $\mathrm{AFm}$ 相の固溶体形成などが起 こり、カルシウムアルミネート系水和物が今以上に複 雑になりXRD/Rietveld 解析でカルシウムアルミネー 卜系水和物のピークが集中する範囲を精度よく定量で きなくなる恐れがある。そこで、セメント硬化体の比 表面積の推定におけるこの問題の対処法として AFt 相 と $\mathrm{AFm}$ 相および $\mathrm{C}_{4} \mathrm{AH}_{13}$ の比表面積が同程度である こと、 $\mathrm{C}_{3} \mathrm{~A}$ の反応率と $\mathrm{C}_{3} \mathrm{AH}_{6}$ の生成量の值が $\mathrm{W} / \mathrm{B} に$ よらず 1 つ回帰式で表せることを利用した、簡易に セメント硬化体の比表面積を求める方法を検討した。即 ち、 $\mathrm{C}_{3} \mathrm{~A}$ から生成する 4 つの水和物のうち、 $\mathrm{AFt}$ 相、 $\mathrm{AFm}$ 相、 $\mathrm{C}_{4} \mathrm{AH}_{13}$ は比表面積の值がほぼ同程度である ため比表面積について考える場合はその 3 種類を区別 する必要はないと考えられ、本推定では AFt 相、 AFm 相、 $\mathrm{C}_{4} \mathrm{AH}_{13}$ の生成量を区別せずに推定を行った。なお、 比表面積の值は 3 つの水和物の比表面積の平均值を使 用した。また、推定方法の検証に用いたセメント硬化体 の $\mathrm{W} / \mathrm{B}(35 \sim 55 \%)$ は回帰式の実験条件内 $(70 \sim 120 \%)$ に収まっていない。これは $\mathrm{C}_{3} \mathrm{~A}$ の水和試料が低 W/B $(35$ 〜 55\%)では練混ぜが不可能だったためである。しかし、 本研究では $\mathrm{C}_{3} \mathrm{~A}$ 反応率と $\mathrm{C}_{3} \mathrm{AH}_{6}$ 生成量の関係は $\mathrm{W} / \mathrm{B}$ に依存しないと仮定して推定を行った。

$\mathrm{C}_{3} \mathrm{AH}_{6}$ 生成量は 3.2 の関係を用いて $\mathrm{C}_{3} \mathrm{~A}$ の反応率 を基に算出した。また、セメント中では $\mathrm{C}_{4} \mathrm{AF}$ からも $\mathrm{C}_{3} \mathrm{AH}_{6}$ は生成される。本研究では、 $\mathrm{C}_{4} \mathrm{AF}$ は式[5]によ り反応すると仮定して検討を進めた。本来ならば $\mathrm{C}_{4} \mathrm{AF}$ からも $\mathrm{AFm}$ 相等が生成されるが、今回の研究では $\mathrm{C}_{4} \mathrm{AF}$ から $\mathrm{AFm}$ 相等は生成されないと仮定した。

$$
C_{4} A F+2 C H+10 H \rightarrow C_{3} A H_{6}+C_{3} F_{6}
$$

以下に、 $\mathrm{C}_{3} \mathrm{AH}_{6}$ の生成量と 3 つの水和物の生成量の 算出方法の詳細を記す。また、Fig. 6 にこの推定方法の 手順を表したフローチャートを示す。

$\mathrm{C}_{3} \mathrm{AH}_{6}$ は $\mathrm{C}_{3} \mathrm{~A}$ から生成されるものと $\mathrm{C}_{4} \mathrm{AF}$ から生 成されるものがある。 $\mathrm{C}_{3} \mathrm{~A}$ 由来の $\mathrm{C}_{3} \mathrm{AH}_{6}$ 生成量はセ 


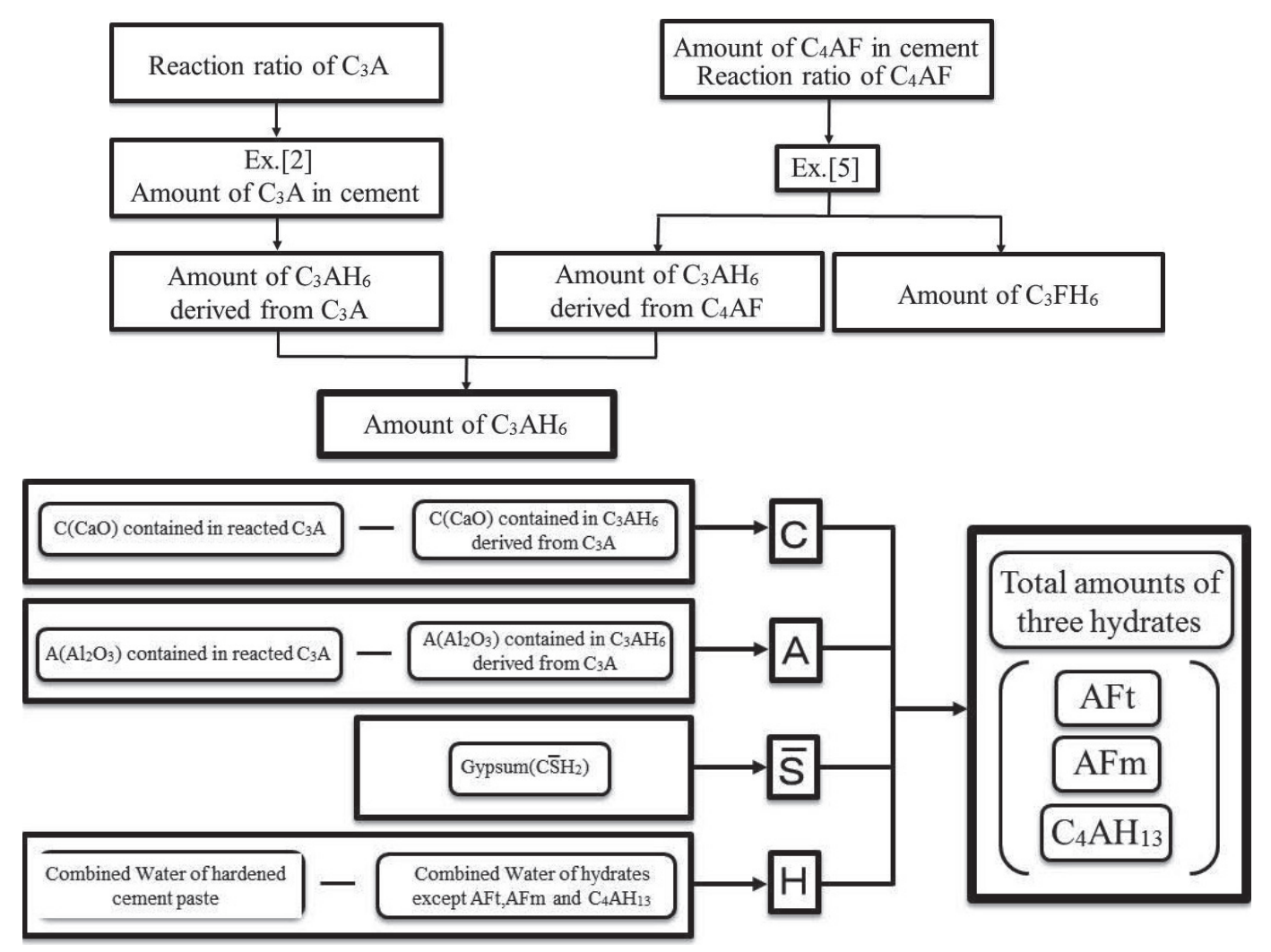

Fig. 6 Flow chart showing the proceeding of simple method of estimation

メント中の $\mathrm{C}_{3} \mathrm{~A}$ 量と反応率、 3.2 の $\mathrm{C}_{3} \mathrm{~A}$ の反応率と $\mathrm{C}_{3} \mathrm{AH}_{6}$ 生成量の関倸の式 [2] 老用いて算出した。 $\mathrm{C}_{3} \mathrm{~A} の$ 水和反応の検討で用いた試料とセメント中の石膏量は同 一でないが、セメント硬化体は材料として石膏を含有 しているため、式[2]を用いた。 $\mathrm{C}_{4} \mathrm{AF}$ 由来の $\mathrm{C}_{3} \mathrm{AH}_{6}$ 生 成量についてもセメント中の $\mathrm{C}_{4} \mathrm{AF}$ 量と反応率、式 [5] を用いて算出した。 $\mathrm{C}_{3} \mathrm{~A}$ 由来の $\mathrm{C}_{3} \mathrm{AH}_{6}$ と $\mathrm{C}_{4} \mathrm{AF}$ 由来の $\mathrm{C}_{3} \mathrm{AH}_{6}$ の合計を、 $\mathrm{C}_{3} \mathrm{AH}_{6}$ の生成量とした。 $\mathrm{C}_{3} \mathrm{FH}_{6}$ の生 成量は $\mathrm{C}_{4} \mathrm{AF}$ 由来の $\mathrm{C}_{3} \mathrm{AH}_{6}$ 生成量を求める方法と同様 に算出した。

$\mathrm{AFt}$ 相、 $\mathrm{AFm}$ 相、 $\mathrm{C}_{4} \mathrm{AH}_{13}$ の 3 つをまとめた生成 量を算出した。3 水和物はすべて $\mathrm{CaO}(\mathrm{C}) 、 \mathrm{Al}_{2} \mathrm{O}_{3}(\mathrm{~A})$ 、 $\mathrm{SO}_{3}(\overline{\mathrm{S}}) 、 \mathrm{H}_{2} \mathrm{O}(\mathrm{H})$ で構成されて㧍り $\left(\mathrm{C}_{4} \mathrm{AH}_{13}\right.$ は $\overline{\mathrm{S}}$ なし $) 、$ それぞれの量の物質収支で計算した。まず C は材料と なる $\mathrm{C}_{3} \mathrm{~A}$ 量と反応率を用いて、反応した $\mathrm{C}_{3} \mathrm{~A}$ 量を算出し、 そこに含まれている $\mathrm{C}$ 量を計算した。次に、先に求め た $\mathrm{C}_{3} \mathrm{~A}$ 由来の $\mathrm{C}_{3} \mathrm{AH}_{6}$ 中に含まれている $\mathrm{C}$ 量を計算し、 反応した $\mathrm{C}_{3} \mathrm{~A}$ 中の $\mathrm{C}$ からアルミネート相由来の $\mathrm{C}_{3} \mathrm{AH}_{6}$ 中の C を差し引くことにより、 $\mathrm{AFt}$ 相、 $\mathrm{AFm}$ 相中に 存在する C 量を決定した。A についても C と同様、反 応した $\mathrm{C}_{3} \mathrm{~A}$ 中の $\mathrm{A}$ から $\mathrm{C}_{3} \mathrm{~A} の \mathrm{C}_{3} \mathrm{AH}_{6}$ 中の $\mathrm{A}$ を差し 引くことにより決定した。 $\overline{\mathrm{S}}$ は石膏から供給され、 $\mathrm{C}_{3} \mathrm{~A}$ の水和反応の検討の際、材齢 1 日で石膏は消費されると いうことが確認できた。従って、セメント硬化体では石 膏はすべて反応したと仮定し、材料の石亮中の $\overline{\mathrm{S}}$ 量を 3 つの水和物中に存在する $\overline{\mathrm{S}}$ 量とした。 $\mathrm{H}$ に関しては、2.5

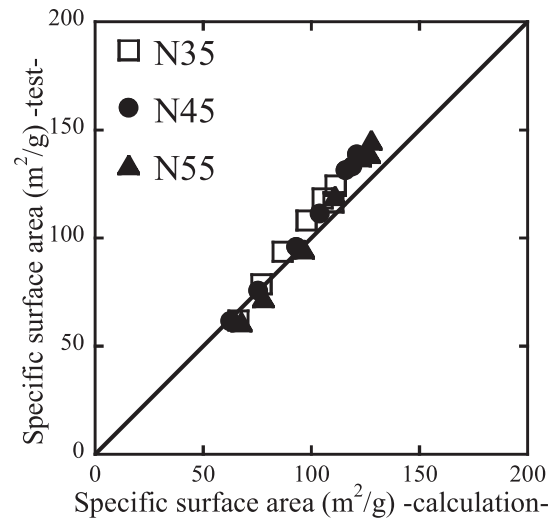

Fig. 7 Comparison between test value and calculation value of specific surface area by simple method of estimation

（3）により求めた $\mathrm{C}-\mathrm{S}-\mathrm{H}$ 量、 $\mathrm{CH}$ 量、算出した $\mathrm{C}_{3} \mathrm{AH}_{6}$ 量、 $\mathrm{C}_{3} \mathrm{FH}_{6}$ 量を基にそれぞれの水和物中の結合水量を計算 し、セメント硬化体の結合水量から各水和物中の結合水 量を引くことで 3 つの水和物中の $\mathrm{H}$ 量を求めた。Fig. 7 に推定結果の計算値と実測値の比較を示す。

Fig. 7 が示すように、カルシウムアルミネート系水和 物のうち $\mathrm{AFt}$ 相、 $\mathrm{AFm}$ 相、 $\mathrm{C}_{4} \mathrm{AH}_{13}$ を区別せずに扱 い、 $\mathrm{C}_{3} \mathrm{~A}$ 反応率と $\mathrm{C}_{3} \mathrm{AH}_{6}$ の生成量から比表面積の計算 を行っても、Fig. 5 が示す各水和物量を定量した推定方 法と同様の精度でセメント硬化体の比表面積の推定が可 能となった。また、本研究では $\mathrm{C}_{4} \mathrm{AH}_{13}$ に打ける結合水 
量の変化に対して、 $\mathrm{C}_{4} \mathrm{AH}_{13}$ を代表值として仮定し、推 定を行っているが、実験結果として上述のような精度で 推定が可能となったことから、本研究の範囲内では結合 水量の変化によるセメント硬化体の比表面積への影響は 小さかったものと考えられる。さらに、本推定法では、 $\mathrm{C}_{4} \mathrm{AF}$ の水和反応を式[5]のように簡略して扱っており、 加えて、水和物の比表面積に関してもセメント中のもの と合成したものを同じと仮定している。しかし、水和温 度が異なることで結晶成長度が異なり比表面積に変化が 起こることも考えられるため、推定精度のさらなる向上 のためには上記の点を今後詳細に検討する必要があると 考えられる。

ただし、この推定方法であれば、本研究において $\mathrm{C}_{4} \mathrm{AH}_{13}$ の結合水量の変化を考慮せずに $\mathrm{C}_{4} \mathrm{AH}_{13}$ のみ で推定を行っても精度よく推定が出来ること、また、 $\mathrm{C}_{4} \mathrm{AH}_{13}$ と $\mathrm{AFm}$ 相の比表面積が同等であるためこの固 溶体の比表面積も同等であると考えられること、以上の 2 つを踏まえ、本研究の実験条件の範囲内では 3.4 の冒 頭で述べたような問題が発生しても、各クリンカーの反 応率さえ求めればカルシウムアルミネート系水和物のう ち $\mathrm{C}_{3} \mathrm{AH}_{6}$ 以外を区別せずにセメント硬化体の比表面積 を推定することが可能となるものと考えられる。

\section{4. まとめ}

本研究では、アルミネート相の水和反応の検討を行い、 その結果を利用してセメント硬化体の比表面積の推定を 行った。

その結果、本研究の実験条件の範囲内において以下の 結論を得た。

1）アルミネート相の反応率と $\mathrm{C}_{3} \mathrm{AH}_{6}$ 生成量の関係は 養生温度や石亳の有無には依存するが結晶構造の差 異や水結合材比には依存しないことがわかった。

2) カルシウムアルミネート系水和物において $\mathrm{C}_{3} \mathrm{AH}_{6}$ のみ比表面積は小さく、 $\mathrm{AFt}$ 相、 $\mathrm{AFm}$ 相、 $\mathrm{C}_{4} \mathrm{AH}_{13}$ は比表面積が大きくなった。また、 $\mathrm{C}_{3} \mathrm{AH}_{6}$ がセメ ント硬化体中のカルシウムアルミネート系水和物の 比表面積に及ぼす影響は非常に小さい。

3）セメント硬化体全体の比表面積を推定する場合に は、カルシウムアルミネート系水和物の比表面積を
考慮することにより、考慮しない場合と比べて計算 值と実測值がより近い值となった。

4）セメント硬化体中の水和物と合成水和物の比表面積 が同じであり、低 $\mathrm{W} / \mathrm{B}$ でも $\mathrm{C}_{3} \mathrm{~A}$ 反応率と $\mathrm{C}_{3} \mathrm{AH}_{6}$ 生成量の関係は $\mathrm{W} / \mathrm{B}$ に依存しないと仮定した場 合、アルミネート相の反応率と $\mathrm{C}_{3} \mathrm{AH}_{6}$ 生成量の関 係を利用し、他の 3 つの水和物 (AFt 相、 $\mathrm{AFm}$ 相、 $\left.\mathrm{C}_{4} \mathrm{AH}_{13}\right)$ をそれぞれ区別せずに扱っても硬化体中の カルシウムアルミネート系水和物の比表面積を評価 することが可能である。

\section{謝辞：}

本研究は、科学研究費補助金 (課題番号：21360204)に より行ったものであることを付記し、謝意を表します。

\section{参考文献：}

1）須田裕哉、土田詩織、佐伯竜彦：セメント系硬化体 の水和物の比表面積に関する研究、セメント・コン クリート論文集、No. 65、pp. 103-110（2011）

2）大門正機、坂井悦郎：社会環境マテリアル セメ ント系材料の使命と持続可能な社会、技術書院、 pp. 75-108 (2009)

3) G. Yamaguchi and S. Takagi. : The Analysis of Portland Cement Clinker, Proceeding of the 5th International Symposium on the Chemistry of Cement. Tokyo, Vol. 1, pp. 181-218 (1969)

4) 李琮揆、大場陽子、坂井悦郎: $\mathrm{C}_{3} \mathrm{~A}-\mathrm{CaCO}_{3}-\mathrm{H}_{2} \mathrm{O}$ 系の水和反応、セメント・コンクリート論文集、 No. 51、pp. 38-43 (1997)

5) W. Dosch : Interlamellar Reactions of Tetracalcium Aluminate Hydrates with Water and Organic Compounds, Clays and Clay Minerals, Vol. 15, No. 1, pp. 273-292 (1967)

6）社団法人セメント協会：セメント化学専門委員会報 告、セメント水和物や硬化体の水和停止方法の検討、 pp. 63-66（2008）

7）中村明則ほか：ケイ酸カルシウム水和物による塩化 物イオン、硫酸イオンおよびリン酸イオンの収着、 日本化学会誌、No. 6、pp. 415-420 (1999) 


\title{
FUNDMENTAL STADY ON THE ESTIMATION METHOD OF THE SPESIFIC SURFACE AREA OF HARDENED CEMENT PASTE CONSIDERING CALCIUM ALUMINATE HYDRATES
}

\author{
Masanari TERATO*1 ${ }^{*}$, Yuya SUDA ${ }^{* 2}$, Tsuyoshi SAITO*3 and Tatsuhiko SAEKI ${ }^{* 3}$
}

*1 NIIGATA UNIVERSITY, Graduate school of Science and Technology (8050, Ikarashi Ninocho, Nishi-Ku, Niigata-shi, Niigata 950-2181, Japan)

*2 Toyota national College of TeChnology, Department of Civil Engineering (2-1, Eisei-cho, Toyota-shi, Aichi 471-8525, Japan)

*3 NIIGATA UNIVERSITY, Department of Civil Engineering (8050, Ikarashi Nino-cho, Nishi-Ku, Niigata-shi, Niigata 950-2181, Japan)

\begin{abstract}
The specific surface area, which is a micro-structure of hydration products, is an important physical property of concrete. It has been clarified that the specific surface area affects mass transferred, adsorption of ions in hardened cement paste and shrinkage of hardened cement paste. These phenomena affect concrete durability. Therefore, the specific surface area of concrete should be estimated accurately in order to estimate the concrete performance.

It was clarified that $\mathrm{C}-\mathrm{S}-\mathrm{H}$ affected the specific surface area of hardened cement paste. However, the specific surface area can not be estimated only by the specific surface area of $\mathrm{C}-\mathrm{S}-\mathrm{H}$, and it is needed to consider the specific surface area of calcium aluminate hydrates.

The purpose of this study is to clarify the estimation method of the specific surface area of hardened cement paste considering calcium aluminate hydrates. From the experimental results, the relationship between the reaction ratio of $\mathrm{C}_{3} \mathrm{~A}$ and the amount of $\mathrm{C}_{3} \mathrm{AH}_{6}$ can be formulated independent of water-binder ratio. Moreover, the specific surface area of calcium aluminate hydrates in hardened cement paste can be estimated by using only the reaction ratio of $\mathrm{C}_{3} \mathrm{~A}$ and the amount of $\mathrm{C}_{3} \mathrm{AH}_{6}$. The total amount of $\mathrm{AFt}, \mathrm{AFm}$ and $\mathrm{C}_{4} \mathrm{AH}_{13}$ can be calculated from the reaction ratio of $\mathrm{C}_{3} \mathrm{~A}$ and the amount of $\mathrm{C}_{3} \mathrm{AH}_{6}$. The specific surface area of $\mathrm{C}_{3} \mathrm{AH}_{6}$ is too small in comparison of those of $\mathrm{AFt}, \mathrm{AFm}$ and $\mathrm{C}_{4} \mathrm{AH}_{13}$. Therefore, the specific surface area of $\mathrm{C}_{3} \mathrm{AH}_{6}$ can be negligible when estimating the specific surface area of hardened cement paste. The total specific surface area of calcium aluminate hydrates can be estimated from the total amount of $\mathrm{AFt}, \mathrm{AFm}$ and $\mathrm{C}_{4} \mathrm{AH}_{13}$ without determining amount of each three hydration products can not be estimated quantitatively.
\end{abstract}

KEY WORDS : Calcium aluminate hydrates, Physical property, Specific surface, Aluminate phase, $\mathrm{C}_{3} \mathrm{AH}_{6}$ 